\title{
Prevalence of smoking and its association with health-related behaviours among Iranian university students: a large-scale study
}

Masoume Mansouri, ${ }^{1}$ Omid Sadeghi, ${ }^{2,3}$ Payam Roshanfekr, ${ }^{4}$ Farshad Sharifi, ${ }^{5}$ Mehdi Varmaghani, ${ }^{6}$ Hamid Yaghubi, ${ }^{7}$ Sonia Ghaffari ${ }^{8}$ and Mohammad Reza Masjedi ${ }^{8}$

${ }^{1}$ Student Health Services, Students' Health and Consultation Centre, Tarbiat Modares University, Tehran, Islamic Republic of Iran. ${ }^{2}$ Students' Scientific Research Centre; ${ }^{3}$ Department of Community Nutrition, School of Nutritional Sciences and Dietetics; ${ }^{5}$ Elderly Health Research Centre, Endocrinology and Metabolism Population Sciences Research Institute, Tehran University of Medical Sciences, Tehran, Islamic Republic of Iran. ${ }^{4}$ Social Welfare Management Research Center, University of Social Welfare and Rehabilitation Sciences, Tehran, Islamic Republic of Iran. ${ }^{6}$ Social Determinants of Health Research Centre, Mashhad University of Medical Sciences, Mashhad, Islamic Republic of Iran. 'Department of Psychology, Shahed University, Tehran, Islamic Republic of Iran. ${ }^{8}$ Tobacco Control Research Centre (Iranian Anti-Tobacco Association), Tehran, Islamic Republic of Iran (Correspondence to: Sonia Ghaffari: sonyaghafary@gmail.com).

\begin{abstract}
Background: The prevalence of smoking and contributing factors among Iranian university students has been paid little attention.

Aims: The aim of this study was to assess the prevalence of smoking in Iranian university students and its association with health-related behaviours.

Methods: This cross-sectional study was carried out on a sample of 82806 Iranian university students admitted in 20122013. Information on demographic characteristics and health-related behaviours, including physical activity, sleep pattern, use of electronic devices and dietary habits, were collected using a standardized questionnaire. Weight and height were measured using a standard protocol and body mass index calculated. Smokers were defined as students who smoked $\geq 1$ cigarette per week.

Results: Smoking was prevalent among 6.0\% of university students (males 6.6\%, females 5.6\%). Moderate physical activity was inversely associated with odds of smoking. A significant positive association was also found between obesity and odds of being a smoker. Higher intake of fruits and dairy products were associated with lower odds of smoking. However, intake of vegetables, fast foods and carbonated beverages was positively associated with smoking. Breakfast consumption was also associated with greater odds of being a smoker.

Conclusions: Demographic characteristics and health-related behaviours, including marital status, occupation, economic status, sleep pattern, physical activity, use of electronic devices and dietary intake, were significantly associated with smoking.

Keywords: smoking prevalence, health-related behaviours, university students, Iran

Citation: Mansouri M; Sadeghi O; Roshanfekr P; Sharifi F; Varmaghani M; Yaghubi H; et al. Prevalence of smoking and its association with health-related behaviours among Iranian university students: a large-scale study. East Mediterr Health J. 2020;26(10):1251-1261. https://doi. org/10.26719/emhj.20.053

Received: 02/06/18; accepted: 12/12/18

Copyright (C) World Health Organization (WHO) 2020. Some rights reserved. This work is available under the CC BY-NC-SA 3.0 IGO license (https:// creativecommons.org/licenses/by-nc-sa/3.o/igo)
\end{abstract}

\section{Introduction}

Smoking is a known risk factor for noncommunicable diseases, including cardiovascular disease (CVD), asthma, COPD, stroke, and cancers $(1,2)$. It imposes a great burden to the health care system and society and is associated with early mortality $(3,4)$. Tobacco is responsible for the 6 million deaths annually worldwide, most in low-income and developing countries (5). Based on the 2010World Health Organization (WHO) report, the prevalence of current smoking was $7.7 \%$ in the United States of America and $11.8 \%$ in the Islamic Republic of Iran, which is considered to be high (6).

Many factors, including health-related behaviours, culture, belief, health literacy, and life problems, are involved in encouraging people to smoke (7-9), but health-related behaviours seem to be important. Various studies have investigated lifestyle, dietary habits, and physical activity are related to smoking (10-12). However, findings are conflicting and limited to western countries. Furthermore, earlier studies have mainly focused on children and adolescents as well as older adults. Hence, youth or university students have been paid less attention. Smoking at a young age might be associated with increased risk of noncommunicable diseases and early death in adulthood (13,14). However, according to WHO predictions, the trend of current tobacco smoking among Iranian adults will be decreased by 2025 (6), so, taking into account the prevalence of smoking at a young age may be essential.

Several studies have shown that stress and psychological distress are the main risk factors for initiation of smoking $(15,16)$. Until now, no study with a large sample size has assessed the relationship between health-related behaviours and smoking among university students in the Middle East countries. 


\section{Methods}

\section{Design}

This cross-sectional study was performed within the framework of the Mental and Physical Health Assessment of University Students (MEPHASOUS) project, which was designed by the Counselling and Health Organization of the Ministry of Science and Technology in Tehran in 2012-2013. The purpose of this study was to assess the present health and behavioural issues of Iranian university students. Detailed information about the MEPHASOUS study has been published elsewhere (17).

\section{Participants}

The current study was conducted university students who were newly admitted to governmental universities from 28 provinces in the Islamic Republic of Iran in the academic year 2012-2013. All students were aged $\geq 18$ years. To gather data, all 151671 students were invited to the health units of universities using announcements or posters. Data on demographic characteristics, anthropometric measures, medical history, and dietary habits were collected from each student. From those who had been invited, 84332 agreed to participate in the project and we had complete data for 82806 students for the final analysis. All participants provided signed informed written consent. The whole project had ethical approval from the Ministry of Science and Technology.

\section{Questionnaire}

A pre-tested questionnaire was used to gather data on demographic characteristics and health-related behaviours (17). The first part of the questionnaire covered demographic characteristics, education, occupation and smoking. To assess economic status, we considered students who had health insurance as "good" economically and those who did not have any type of health insurance as "weak". From previous research, prevalence of smoking and addiction differs among the Iranian provinces (18). To reflect this difference, we categorized students based on the areas where they were living; high-risk, moderate-risk and low-risk areas, determined according to the prevalence of smoking in each area (18). For example, we considered Isfahan and Yazd, where the prevalence of smoking is low, as low-risk areas.

Another part of the questionnaire was about sleep pattern, with 2 questions: "How is your pattern of sleeping and waking?" and "How many hours do you sleep in a day?" To assess physical activity, we asked: "How often do you exercise for $\geq 30$ minutes?" Students who answered "rarely" were considered physically inactive. Use of electronic devices was assessed by the question: "In a day, how many hours do you use electronic devices such as computer, cell phone, and notebook?"

\section{Definition of smoker}

Based on smoking status, we had 4 groups of students: non-smokers, those who smoked cigarettes rarely, those who smoked $<10$ cigarettes per week and those who smoked $\geq 10$ cigarettes per week. Smokers were defined as individuals who smoked one cigarette per week (19).

\section{Dietary habits}

Another part of the questionnaire evaluated dietary intake of certain food groups as well as breakfast eating patterns. The questions were about frequency of consumption of fruits, vegetables, dairy products, fast foods and carbonated beverages. In Iranian culture, fruits are consumed more frequently than the other groups. Therefore, the frequency response categories for fruit consumption were daily compared with vegetables, dairy, fast foods and carbonated beverages which had weekly response categories. Breakfast consumption was assessed by the question: "How many days do you eat breakfast". Those who consumed breakfast less than 1 day/week were considered breakfast skippers.

\section{Anthropometric measures}

Weight was measured with minimal clothing and without shoes using an analogue scale with a precision of $100 \mathrm{~g}(20)$. Height was determined in a standing position without shoes using a tape measure to the nearest $0.5 \mathrm{~cm}$ $(21,22)$. Body mass index (BMI) was calculated as weight in kilograms divided by the square of the height in metres. Students were classified into 4 BMI categories according to WHO criteria (23): $<18.5 \mathrm{~kg} / \mathrm{m}^{2}$ (underweight), $18.5-24.9 \mathrm{~kg} / \mathrm{m}^{2}$ (normal), $25.0-29.9 \mathrm{~kg} / \mathrm{m}^{2}$ (overweight) and $\geq 30.0 \mathrm{~kg} / \mathrm{m}^{2}$ (obese).

\section{Statistical analysis}

The independent sample t-test was used for assessing the continuous variables, including age and BMI, among smokers and non-smokers. In addition, the chi-squared test was applied to assess the distribution of categorical variables among smokers and non-smokers. Binary logistic regression in crude and adjusted models was used to obtain odds ratios (ORs) and related 95\% confidence intervals (CIs) for smoking across categories of demographic characteristics and dietary habits. In the first model, age (continuous) and sex (male/female) were controlled. In the second model, additional adjustment was made for all variables except age group and sleep duration. Due to the adjustment for sleep pattern, we did not include sleep duration in the adjusted models. In addition, BMI was included in the second model as a categorical variable.

All statistical analyses were performed using SPSS, version 19.0; $P$-values were considered significant at $<0.05$.

\section{Results}

Demographic characteristics and dietary habits of smokers and non-smokers are presented in Table 1. Compared to the non-smoker students, smokers were more likely to be older, male, married, graduates, physically inactive, breakfast skippers, having an occupation and using electronic devices. Smokers were less likely to live in a dormitory or in high-risk areas, have a regular sleep pattern 


\begin{tabular}{|c|c|c|c|c|c|}
\hline \multirow[t]{2}{*}{ Characteristic } & \multicolumn{2}{|c|}{ Non-smokers } & \multicolumn{2}{|c|}{ Smokers $^{a}$} & \multirow[t]{2}{*}{ P-value } \\
\hline & Mean & SD & Mean & SD & \\
\hline Age (years) & 21.4 & 4.0 & $21.8 \pm$ & 4.1 & $<0.001$ \\
\hline \multirow[t]{2}{*}{ Body mass index $\left(\mathrm{kg} / \mathrm{m}^{2}\right)$} & 22.5 & 4.03 & $22.6 \pm$ & 3.9 & 0.01 \\
\hline & No. & $\%$ & No. & $\%$ & \\
\hline Age (years) & & & & & $<0.001$ \\
\hline$<20$ & 38413 & 49.4 & 2247 & 45.0 & \\
\hline $20-<25$ & 25095 & 32.2 & 1714 & 34.3 & \\
\hline $25-<30$ & 10396 & 13.4 & 754 & 15.1 & \\
\hline$\geq 30$ & 3910 & 5.0 & 277 & 5.5 & \\
\hline \multicolumn{6}{|l|}{ Sex } \\
\hline (female) & 42613 & 54.8 & 2507 & 50.2 & $<0.001$ \\
\hline Marital status (married) & 7700 & 9.9 & 608 & 12.2 & $<0.001$ \\
\hline \multicolumn{6}{|l|}{ Residence } \\
\hline (dormitory) & 43067 & 56.1 & 2281 & 46.0 & $<0.001$ \\
\hline Living in a high-risk areab & 9893 & 12.7 & 128 & 2.6 & $<0.001$ \\
\hline Education (graduate) ${ }^{c}$ & 29709 & 38.4 & 2239 & 44.9 & $<0.001$ \\
\hline Having occupation & 6027 & 9.4 & 879 & 19.0 & $<0.001$ \\
\hline Economic status (good) & 63483 & 84.6 & 2776 & 56.3 & $<0.001$ \\
\hline Physical activity (inactive) & 12170 & 15.7 & 1080 & 21.8 & $<0.001$ \\
\hline Sleep pattern (regular) & 45772 & 59.3 & 2956 & 61.7 & 0.001 \\
\hline Sleep duration (6-8 hours/day) & 54370 & 58.4 & 2389 & 48.0 & $<0.001$ \\
\hline Electronic device use (rarely) $)^{e}$ & 4561 & 5.9 & 605 & 12.1 & $<0.001$ \\
\hline Brealkfast skippingf & 3565 & 4.6 & 452 & 9.1 & $<0.001$ \\
\hline \multicolumn{6}{|l|}{ Dietary intake } \\
\hline Fruits (> 3 servings/day) & 7847 & 10.1 & 525 & 10.6 & $<0.001$ \\
\hline Vegetables (1 servings/day) & 10558 & 13.6 & 769 & 15.5 & $<0.001$ \\
\hline Dairy products (1 servings/day) & 19448 & 25.0 & 461 & 9.3 & $<0.001$ \\
\hline Fast foods (daily) & 755 & 1.0 & 192 & 3.9 & $<0.001$ \\
\hline Carbonated beverages (daily) & 4528 & 5.9 & 608 & 12.4 & $<0.001$ \\
\hline
\end{tabular}

\section{$S D=$ standard deviation.}

P-value obtained from independent sample t-test or Chi-squared, where appropriate.

aSmokers were defined as students who smoked at least one cigarette per week.

${ }^{b}$ Areas in which prevalence of smoking is high.

'Students who were in MSc and PhD courses were considered graduate students.

${ }^{\mathrm{d}}$ Those who exercised rarely during a week.

${ }^{e}$ Use of computer, cell phone and notebook.

fStudents who consumed breakfast less than 1 day/week were defined as breakfast skippers.

(such as 6-8 hours/day) or good economic status compared with non-smokers.

In terms of dietary habits, smokers among the students were less likely to consume fruits, vegetables and dairy products, and more likely to consume fast foods and carbonated beverages compared with non-smokers.

Multivariate adjusted ORs for being a smoker across categories of demographic variables are shown in Table 2. Compared with single students, those who were married were more likely to be smokers. This association was significant even after taking potential confounders into account (OR $=1.22,95 \%$ CI: 1.07-1.38). Divorced students had greater odds of smoking than those who were single. However, this association was non-significant in the fully adjusted model. A significant positive association was also found between education and smoking (OR
$=1.31,95 \%$ CI: 1.23-1.38). However, in the fully adjusted model, this association was non-significant. Both before and after considering confounders, students with good economic status had lower odds of being smokers compared with those who were economically weak (OR $=0.27,95 \%$ CI: 0.25-0.29). In addition, students who had a job were more likely to be smokers compared with those without a job. This finding was also seen after adjusting for covariates $(\mathrm{OR}=2.42,95 \% \mathrm{CI}: 2.17-2.69)$. A significant inverse association was found between physical activity and smoking. This was also seen even after considering age and sex as covariates (OR $=0.79,95 \%$ CI: $0.73-0.85$ ), but in the fully adjusted model this association was nonsignificant. However, students who practised physical activity 1-2 times/week had 32\% lower odds for smoking 
Table 2 Binary logistic regression for smoking among Iranian students $(n=82$ 806) based on demographic characteristics, $2012-2013$

\begin{tabular}{|c|c|c|c|}
\hline \multirow[t]{3}{*}{ Characteristic } & \multirow{3}{*}{$\begin{array}{l}\text { Unadjusted } \\
\text { OR }(95 \% \mathrm{CI})\end{array}$} & \multicolumn{2}{|c|}{ Adjusted } \\
\hline & & \multirow{2}{*}{$\begin{array}{c}\text { Model } 1 \\
\text { OR }(95 \% \mathrm{CI})\end{array}$} & \multirow{2}{*}{$\begin{array}{c}\text { Model } 2 \\
\text { OR }(95 \% \text { CI })\end{array}$} \\
\hline & & & \\
\hline \multicolumn{4}{|l|}{ Marital status } \\
\hline Single & 1.00 & 1.00 & 1.00 \\
\hline Married & $1.26(1.15-1.37)$ & $1.20(1.08-1.32)$ & $1.22(1.07-1.38)$ \\
\hline Divorced & $2.99(1.61-5.56)$ & $2.89(1.55-5.37)$ & $1.92(0.79-4.66)$ \\
\hline \multicolumn{4}{|l|}{ Education } \\
\hline Undergraduate & 1.00 & 1.00 & 1.00 \\
\hline Graduate & $1.31(1.23-1.38)$ & $1.37(1.25-1.49)$ & $1.05(0.94-1.17)$ \\
\hline \multicolumn{4}{|l|}{ Occupation } \\
\hline None & 1.00 & 1.00 & 1.00 \\
\hline Yes & $2.26(2.09-2.44)$ & $2.54(2.33-2.77)$ & $2.42(2.17-2.69)$ \\
\hline \multicolumn{4}{|l|}{ Economic status } \\
\hline Weak & 1.00 & 1.00 & 1.00 \\
\hline Good & $0.23(0.22-0.24)$ & $0.23(0.22-0.25)$ & $0.27(0.25-0.29)$ \\
\hline \multicolumn{4}{|c|}{ Physical activity (times/week) } \\
\hline Rarely & 1.00 & 1.00 & 1.00 \\
\hline $1-2$ & $0.54(0.50-0.59)$ & $0.54(0.50-0.59)$ & $0.68(0.61-0.75)$ \\
\hline$\geq 3$ & $0.80(0.74-0.86)$ & $0.79(0.73-0.85)$ & $1.00(0.91-1.11)$ \\
\hline \multicolumn{4}{|l|}{ Sleep pattern } \\
\hline Irregular & 1.00 & 1.00 & 1.00 \\
\hline Regular & $1.10(1.04-1.17)$ & $1.09(1.03-1.16)$ & $1.13(1.05-1.23)$ \\
\hline \multicolumn{4}{|c|}{ Sleep duration (hours/day) } \\
\hline $6-8$ & 1.00 & 1.00 & 1.00 \\
\hline$<6$ & $2.73(2.48-3.01)$ & $2.72(2.47-2.99)$ & $2.18(1.91-2.48)$ \\
\hline $8-10$ & $1.24(1.16-1.32)$ & $1.27(1.19-1.35)$ & $1.25(1.16-1.35)$ \\
\hline$>10$ & $3.33(2.89-3.83)$ & $3.43(2.98-3.95)$ & $2.36(1.90-2.93)$ \\
\hline \multicolumn{4}{|c|}{ Electronic devices use (hours/day) } \\
\hline Rarely & 1.00 & 1.00 & 1.00 \\
\hline$<2$ & $0.44(0.39-0.49)$ & $0.41(0.37-0.46)$ & $0.39(0.33-0.45)$ \\
\hline $2-4$ & $0.41(0.37-0.45)$ & $0.39(0.35-0.43)$ & $0.43(0.37-0.49)$ \\
\hline$>4$ & $0.49(0.44-0.54)$ & $0.48(0.43-0.53)$ & $0.58(0.50-0.66)$ \\
\hline \multicolumn{4}{|l|}{$\mathrm{BMI}\left(\mathrm{kg} / \mathrm{m}^{2}\right)$} \\
\hline$<18.5$ & $0.98(0.89-1.07)$ & $1.01(0.92-1.10)$ & $1.11(1.00-1.24)$ \\
\hline $18.5-24.9$ & 1.00 & 1.00 & 1.00 \\
\hline $25.0-29.9$ & $1.09(1.01-1.18)$ & $1.05(0.97-1.13)$ & $1.12(1.02-1.23)$ \\
\hline$\geq 30.0$ & $1.03(0.90-1.18)$ & $1.00(0.87-1.15)$ & $1.23(1.04-1.46)$ \\
\hline
\end{tabular}

$\mathrm{OR}=$ odds ratio; $\mathrm{CI}=$ confidence interval; $\mathrm{BMI}=$ body mass index.

Model 1: age and sex were adjusted.

Model 2: additionally adjustment was made for all variables mentioned in Table 1 except age group and sleep duration.

compared with those who exercised rarely $(\mathrm{OR}=0.68$, 95\% CI: 0.61-0.75).

Students with a regular sleep pattern had slightly greater odds of being a smoker $(\mathrm{OR}=1.10$, 95\% CI: $1.04-$ 1.17) compared with those with irregular sleep pattern. This finding was also observed even after adjusting for potential confounders ( $\mathrm{OR}=1.13,95 \% \mathrm{CI}$ : 1.05-1.23). Furthermore, in both the crude and adjusted models, students who slept $<6$ hours/day $(\mathrm{OR}=2.18,95 \% \mathrm{CI}$ : $1.91-2.48)$ or $>8$ hours/day $(\mathrm{OR}=2.36,95 \% \mathrm{CI}: 1.90-2.93)$ were more likely to be smokers compared with those who slept 6-8 hours/day. There was a significant inverse association between use of electronic devices and odds of being a smoker $(\mathrm{OR}=0.49,95 \% \mathrm{CI}$ : 0.44-0.54). In the fully adjusted model, students who used electronic devices $>4$ hours/day were less likely to be smokers (42\%) than those who used electronic devices rarely $(\mathrm{OR}=0.58,95 \% \mathrm{CI}$ : $0.50-0.66$ ).

Those classed as underweight, overweight and obese were more likely to be smokers compared with normal- 
weight students, even after controlling for confounders. These 3 groups had $11 \%, 12 \%$ and $23 \%$ greater odds of smoking, respectively, compared with those of normal weight (underweight; OR $=1.11,95 \% \mathrm{CI}: 1.00-1.24$, overweight; $\mathrm{OR}=1.12,95 \%$ CI: 1.02-1.23, obese; $\mathrm{OR}=1.23$, 95\% CI: 1.04-1.46).

Multivariate-adjusted ORs for being a smoker across categories of dietary habits are shown on Table 3. Compared with those in the lowest category, students in the highest category for fruit consumption were less likely (55\%) to be smokers (OR $=0.45,95 \%$ CI: $0.40-0.52$ ). The association was seen both before and after taking potential confounders into account $(\mathrm{OR}=0.78,95 \% \mathrm{CI}$ : 0.64-0.96). For vegetable intake we found no significant association with smoking. However, in the fully adjusted model, students in the top category for vegetable consumption had greater odds of being smokers compared with those in the bottom category $(\mathrm{OR}=1.36$,
95\% CI: 1.17-1.57). A significant inverse association was observed between consumption of dairy products and being a smoker. Indeed, after adjusting for potential confounders, students in the highest intake category were less likely (95\%) to be smokers compared with those in the lowest category ( $\mathrm{OR}=0.05,95 \% \mathrm{CI}$ : 0.04-0.06).

After controlling for all confounders, we found no significant association between fast food intake and smoking. However, students who consumed fast foods 1 time/week had $67 \%$ greater odds of being smokers compared with those who consumed these foods rarely $(\mathrm{OR}=1.67,95 \% \mathrm{CI}: 1.27-2.19)$. In both the crude and the adjusted models consumption of carbonated beverages was positively associated with being a smoker ( $O R=1.59$, 95\% CI: 1.47-1.73). Those who ate breakfast every day had a lower likelihood $(49 \%)$ of being smokers (OR $=0.51,95 \%$ CI: 0.46-0.56) compared with students who rarely ate breakfast (< 1 day/week). However, in the fully adjusted

\begin{tabular}{|c|c|c|c|}
\hline Food & $\begin{array}{l}\text { Unadjusted } \\
\text { OR ( } 95 \% \text { CI) }\end{array}$ & $\begin{array}{c}\text { Model } 1 \\
\text { OR }(95 \% \text { CI })\end{array}$ & $\begin{array}{c}\text { Model 2 } \\
\text { OR }(95 \% \text { CI })\end{array}$ \\
\hline \multicolumn{4}{|c|}{ Fruit (servings/day) } \\
\hline Rarely & 1.00 & 1.00 & 1.00 \\
\hline$\leq 1$ & $0.52(0.47-0.59)$ & $0.52(0.47-0.59)$ & $0.80(0.67-0.95)$ \\
\hline $2-3$ & $0.34(0.30-0.38)$ & $0.34(0.31-0.38)$ & $0.68(0.57-0.82)$ \\
\hline$>3$ & $0.45(0.40-0.52)$ & $0.47(0.41-0.54)$ & $0.78(0.64-0.96)$ \\
\hline \multicolumn{4}{|c|}{ Vegetables (servings/week) } \\
\hline Not weekly & 1.00 & 1.00 & 1.00 \\
\hline 1 & $0.97(0.89-1.06)$ & $0.98(0.90-1.07)$ & $1.25(1.22-1.40)$ \\
\hline $2-3$ & $0.83(0.76-0.91)$ & $0.84(0.77-0.92)$ & $1.21(1.07-1.36)$ \\
\hline 1/day & $1.07(0.96-1.19)$ & $1.10(0.99-1.22)$ & $1.36(1.17-1.57)$ \\
\hline \multicolumn{4}{|c|}{ Dairy products (servings/week) } \\
\hline Not weekly & 1.00 & 1.00 & 1.00 \\
\hline 1 & $0.32(0.30-0.35)$ & $0.32(0.30-0.35)$ & $0.35(0.31-0.39)$ \\
\hline $2-3$ & $0.09(0.08-0.10)$ & $0.09(0.08-0.10)$ & $0.08(0.07-0.09)$ \\
\hline 1/day & $0.06(0.05-0.07)$ & $0.06(0.05-0.07)$ & $0.05(0.04-0.06)$ \\
\hline \multicolumn{4}{|c|}{ Fast foods (times/week) } \\
\hline Rarely & 1.00 & 1.00 & 1.00 \\
\hline 1 & $3.93(3.32-4.65)$ & $4.08(3.44-4.83)$ & $1.67(1.27-2.19)$ \\
\hline $2-3$ & $1.21(1.11-1.31)$ & $1.26(1.16-1.37)$ & $1.06(0.94-1.18)$ \\
\hline Every day & $0.85(0.79-0.91)$ & $0.88(0.82-0.94)$ & $0.93(0.86-1.02)$ \\
\hline \multicolumn{4}{|c|}{ Carbonated beverages (times/week) } \\
\hline Rarely & 1.00 & 1.00 & 1.00 \\
\hline $1-2$ & $2.66(2.42-2.92)$ & $2.71(2.46-2.98)$ & $2.33(2.03-2.67)$ \\
\hline Every day & $1.45(1.36-1.54)$ & $1.46(1.37-1.55)$ & $1.59(1.47-1.73)$ \\
\hline \multicolumn{4}{|c|}{ Brealfast consumption (days/week) } \\
\hline$<1$ & 1.00 & 1.00 & 1.00 \\
\hline $1-2$ & $0.41(0.36-0.47)$ & $0.41(0.36-0.47)$ & $0.69(0.58-0.83)$ \\
\hline $3-4$ & $0.44(0.39-0.50)$ & $0.44(0.39-0.49)$ & $0.96(0.81-1.14)$ \\
\hline Every day & $0.51(0.46-0.56)$ & $0.51(0.46-0.56)$ & $1.33(1.13-1.56)$ \\
\hline
\end{tabular}

$\mathrm{OR}=$ odds ratio CI = confidence interval.

Model 1: age and sex were adjusted.

Model 2: additionally adjustment was made for all variables mentioned in Table 1 except age group and sleep duration. 
model, this association was positive: students who consumed breakfast every day were $33 \%$ more likely to be smokers compared with those who rarely ate breakfast $(\mathrm{OR}=1.33$, 95\% CI: 1.13-1.56).

\section{Discussion}

In this study, the prevalence of smoking among Iranian students was $6.0 \%$, lower than the mean for Iranian adults $(11.8 \%, 2015$ report) (6). However, the prevalence of smoking among female students in the current study (5.6\%) was higher than the mean prevalence reported for Iranian women (1.3\%).

In a 2008-2009 study in the United States of America among 105012 university students, $16.8 \%$ were cigarette smokers (24). In a large survey in different regions of Europe, the prevalence of tobacco product use ranged from $20 \%$ to $35 \%$ among individuals aged $15+$ years (25). Therefore, it seems that the prevalence of smoking among Iranian university students is lower than in western countries. Cultural and religious beliefs might be the reasons for the lower prevalence of smoking among Iranian students compared with western nations. In addition, based on WHO reports, the prevalence of smoking is decreasing among Iranian youth and adults (6). However, finding the risk factors of smoking helps to develop strategies to hasten this reduction.

We found that marriage was positively associated with smoking. Similarly, Pennanen et al. reported that men living with a spouse were more likely to be smokers compared with single men (26). This finding was also seen in a similar study on Iranian adults (27). An increase in living expenses and responsibilities after marriage can enhance psychological stress and encourage individuals to smoke cigarettes to deal with this stress $(28,29)$. However, we adjusted for economic status on the association between marital status and smoking, and we cannot completely exclude it. We found that students who had a job were more likely to be smokers than those who did not. Azagba et al. reported that having a job and the related stress had a positive and statistically significant impact on smoking intensity (30). In contrast, a study in Germany showed that unemployment was a reason for high prevalence of smoking (31). Overall, it seems that having a job, particularly a high-stress job and unemployment increase the odds of cigarette smoking through increased psychological stress $(31,32)$.

We found that moderate physical activity was inversely associated with smoking. In line with this finding, a previous Iranian study reported that cigarette cessation was easier in physically active smokers than inactive individuals (27). This finding was also reported in a study from Malaysia (33). We found no study indicating a positive or non-significant association between physical activity and smoking. It seems that physical activity alleviates the psychological distress that is associated with smoking (34-36). In addition, physical activity fills the leisure time of students that may otherwise be spent smoking. The lack of a significant association for students who exercise $\geq 3$ time/week might be explained by the presence of athletes or students who did professional sports in this group. Previous research has shown a high prevalence of cigarette and tobacco smoking among athletes (37).

Students with a regular sleep pattern were more likely to be smokers compared with those with an irregular pattern. In addition, students who slept $<6$ or $>8$ hours/ day had greater odds of smoking compared with those who slept 6-8 hours/day. In a recent cross-sectional study, insomnia was positively associated with smoking in adults (38). In a 2010 Iranian study, sleeping $<6$ or $>9$ hours/day was associated with an increased risk of cigarette smoking (27). We found no study that reported a regular sleep pattern was positively associated with smoking. Observed associations between sleep pattern and sleep duration with smoking might be mediated by psychological disorders. Students with these disorders may have regular sleep pattern and longer sleep duration because of the nature of the disease or because of the medication $(39,40)$.

We found that using electronic devices was inversely associated with smoking. Contrary to our finding, previous studies have indicated that addictive internet use was positively associated with smoking $(41,42)$. However, the students who participated in our study were not addicted. It is possible that people who use electronic devices more have more information about smoking harms. Greater use of electronic devices is associated with greater health literacy (43), and this is inversely associated with smoking (44).

In the current study, underweight, overweight and obese students had greater odds of smoking compared with normal-weight students. In a recent cross-sectional study, obese young women were $21.2 \%$ more likely to be smokers than those of normal weight (45). In a study on medical students in Saudi Arabia, weight and BMI were higher among smokers than non-smokers (46). In contrast, in an earlier study, weight loss was higher in smokers than non-smokers (47). However, findings from 2 recent Iranian studies showed a significant inverse association between smoking and obesity $(48,49)$. These inconsistent results may be due to differences in the quality of the studies and different populations. For example, in one study, none of confounders were adjusted (48), while in our study, a large number of confounding variables were controlled for.

Similar to the findings of previous research (47), we also found a significant positive association between underweight and smoking. Previous studies have shown a high prevalence of psychological disorders such as depression and anxiety among underweight, overweight and obese individuals (50-52). These disorders are risk factors of smoking. It is important to note that the association between obesity and smoking may be bidirectional, meaning that smoking may contribute to obesity and vice versa. Recently, it has been shown that in smokers leptin concentrations are higher than in nonsmokers (53). Nicotine in smokers induces peripheral 
leptin resistance through lowering gene expression of leptin receptors (54). Leptin is a key hormone that suppresses appetite and prevents obesity (54). Further studies, particularly those of a prospective nature, are needed to shed light facts on the association between obesity and smoking.

In our study, students who ate breakfast every day were more likely to be smokers than breakfast skippers. In line with our findings, a study on adolescents in China reported that breakfast consumption was more common among smokers than non-smokers (55). In contrast, a study in the United States of America showed that prevalence of smoking was significantly higher in individuals who skipped breakfast than in those who ate breakfast (56). These differences in findings in this regard might be due to a different definition of smokers. In addition, different quality studies and the different statistical methods used to assess the associations may offer other explanations for the discrepancies. The exact mechanism for the association between breakfast consumption and smoking is unclear. Further studies are needed to reveal the effects of breakfast consumption on smoking and mechanisms in this regard.

We found that intake of fruits and dairy products was inversely associated with smoking, while intake of vegetables and carbonated beverages and moderate intake of fast foods were positively associated with smoking. In line with these findings, a Korean cross-sectional study showed that adherence to an unhealthy dietary pattern (low amount of fruits and dairy products; rich in fast foods and carbonated beverages) was more common in smokers (57). This was also reported in a cross-sectional study in Tehran (58). Haibach et al. reported that fruit, but not vegetable, consumption among American adolescents was inversely associated with smoking frequency (59). In a cross-sectional study in China among individuals who consumed tea and sweetened beverages daily, the likelihood of smoking behaviours was lower for those who consumed these beverages less frequently (60). In a study in South Korea, consumption of fruits and dairy products was lower among smokers than non-smokers, and smokers consumed fast foods more often than nonsmokers (61). Another Korean study also showed that smokers consumed vegetables less frequently than nonsmokers (62). Perhaps the positive association between vegetable consumption and smoking we observed might be an attempt to reduce the harmful effects of cigarette smoking. Overall, the inverse association with smoking for fruits and dairy products and the positive association for fast foods and carbonated beverages may be a result of greater health literacy: students who choose healthy foods and consume a low amount of unhealthy foods es have greater health literacy. Therefore, greater health literacy is associated with lower odds of being a smoker.

In the current study, we found that participants with good economic status were less likely to be smokers compared with those who were weak economically. In line with our findings, a Malaysian study reported a lower prevalence of smoking among rich individuals compared with poor ones (63). This finding was also seen in a study from Indonesia (64). In addition, it should be noted that economic status, as an important confounder, can affect estimates. In addition to the link with smoking, exposure variable including dietary intakes, education, physical activity, sleep pattern and marital status, can be affected by economic status (65-67). Despite the adjustment for economic status, we cannot exclude the effect of this variable completely because we assessed economic status by only considering health insurance. Furthermore, some associations obtained in the current study might be mediated by economic status. For example, intake of fruits and dairy produce is greater in rich individuals, who smoke cigarette less than poor people (65). In addition, the inverse association between physical activity and smoking might be mediated by economic status: physically active individuals may have better economic status, and consequently lower likelihood of being a smoker, than those who were physically inactive (67).

The most important strength of the current study was the large sample size. As far as know, our study was the first in the Middle East to assess smoking and its association with demographic, anthropometric and health-related behaviours in a large sample size of students. However, some limitations should be considered. The main limitation is the cross-sectional design of our study, which prohibits us inferring causality. Therefore, further prospective studies are needed to confirm our findings. In addition, to assess dietary intake, we used a dietary habits questionnaire. It would be better to use the food frequency questionnaire to assess the long-term dietary intake of students. Furthermore, we had no data on age of starting smoking, years of smoking, number of cigarette per day and patterns of smoking to categorize students as experimenter, current, daily or occasional smoker. Despite controlling for several confounders, we cannot exclude the possible effects of residual confounders such as influence of roommates who smoke, family history of smoking and psychological disorders on the association between different exposure variables and smoking.

\section{Acknowledgement}

We would like to thank the well trained staff of the Counselling and Health Organization of the Ministry of Science and Technology. Special thanks also to the university health centre directors who run the screening programme and encouraged students to participate in the health screening programme.

Funding: None

Competing interests: None declared. 


\section{Prévalence du tabagisme et son association avec les comportements liés à la santé parmi les étudiants iraniens : étude à grande échelle}

\section{Résumé}

Contexte : La prévalence du tabagisme et les facteurs qui y contribuent parmi les étudiants iraniens n'ont pas fait l'objet d'une grande attention.

Objectifs : La présente étude visait à évaluer la prévalence du tabagisme chez les étudiants iraniens et son association avec les comportements liés à la santé.

Méthodes : La présente étude transversale a été réalisée dans un échantillon de 82806 étudiants iraniens admis à l'université en 2012-2013. Des informations sur les caractéristiques démographiques et les comportements liés à la santé, incluant l'activité physique, les habitudes de sommeil, l'utilisation d'appareils électroniques et les habitudes alimentaires ont été recueillies à l'aide d'un questionnaire standardisé. Le poids et la taille ont été mesurés au moyen d'un protocole standard et l'indice de masse corporelle a été calculé. Les fumeurs ont été définis comme ceux qui fumaient une cigarette ou plus par semaine.

Résultats : Le tabagisme était prévalent chez 6,0\% des étudiants (hommes : 6,6\% ; femmes : 5,6\%). Une activité physique modérée était inversement associée avec la probabilité de fumer. Une corrélation positive significative a été observée entre l'obésité et la probabilité d'être fumeur. Une plus grande consommation de fruits et de produits laitiers était associée avec une probabilité plus faible de fumer. En revanche, on a noté une corrélation positive entre la consommation de légumes, d'aliments de restauration rapide et de boissons gazeuses et le tabagisme. La prise de petit-déjeuner était également associée à une plus grande probabilité d'être fumeur.

Conclusions : Les caractéristiques démographiques et les comportements liés à la santé, incluant la situation matrimoniale, professionnelle et économique, les habitudes de sommeil, l'activité physique, l'utilisation d'appareils électroniques et les apports alimentaires, entretenaient un lien significatif avec le tabagisme.

\footnotetext{
انتشار التدخين وارتباطه بالسلو كيات المتعلقة بالصحة بين طلاب الجامعات الإير انية: دراسة واسعة النطاق معصوم المنصوري، عميد صادقي، بيام رشنفكر، فرشاد شريفي، مهدي فارماغاني، حميد يعقوبي، سونيا غفاري، محمد رضا مسجدي الخالإنة الخلفية: لم يجظَ انتشار التدخين والعوامل المساهمة فيه سوى باهتهام ضئيل بين طلاب الجامعات الإيرانية. الأهداف: هدفت هذه الدر اسة إلى تقييم انتشار التدخين بين طلابِ الجامعات الإيرانية، وارتباطه بالسلوكيات المتعلقة بالصحة.

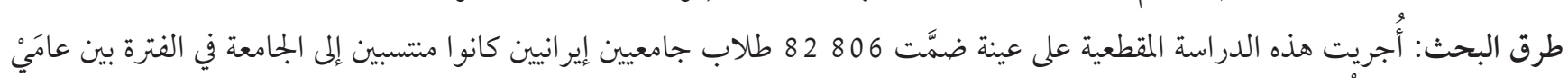

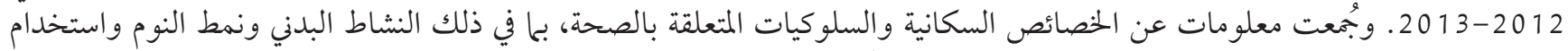

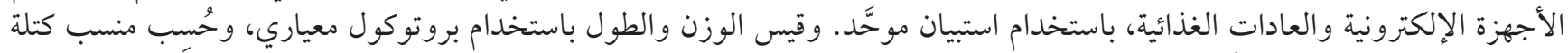

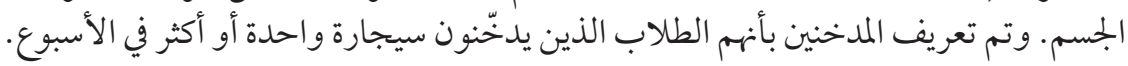
النتائج: كان التدخين منتشراً بين 0.0

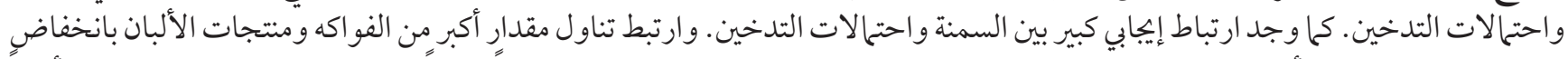

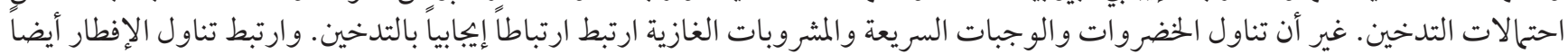
باحتمالات أكبر للتدخين.

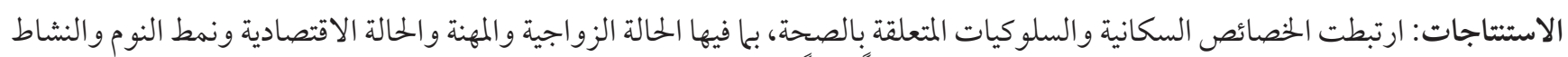

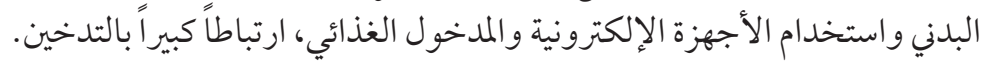

\section{References}

1. Albertsen IE, Overvad TF, Lip GY, Larsen TB. Smoking, atrial fibrillation, and ischemic stroke: a confluence of epidemics. Curr Opin Cardiol. 2015;30:512-7. doi:10.1097/HCO.0000000000000205

2. Peters SA, Huxley RR, Woodward M. Smoking as a risk factor for stroke in women compared with men: a systematic review and meta-analysis of 81 cohorts, including 3,980,359 individuals and 42,401 strokes. Stroke. 2013;44:2821-8. PMID:23970792

3. Chang CM, Corey CG, Rostron BL, Apelberg BJ. Systematic review of cigar smoking and all cause and smoking related mortality. BMC Public Health. 2015;15:390. doi:10.1186/s12889-015-1617-5 
4. Pan A, Wang Y, Talaei M, Hu FB. Relation of smoking with total mortality and cardiovascular events among patients with diabetes mellitus: a meta-analysis and systematic review. Circulation. 2015;132:1795-804. doi:10.1161/CIRCULATIONAHA.115.017926

5. WHO global report: mortality attributable to tobacco. Geneva: World Health Organization; 2012 (https://www.who.int/tobacco/ publications/surveillance/rep_mortality_attributable/en/, accessed 12 November 2019)..

6. WHO global report on trends in prevalence of tobacco smoking 2015. Ggeneva: World Health Organization; 2015 (https://apps. who.int/iris/handle/10665/156262, accessed 12 November 2019.

7. Al-Kaabba AF, Saeed AA, Abdalla AM, Hassan HA, Mustafa AA. Prevalence and associated factors of cigarette smoking among medical students at King Fahad Medical City in Riyadh of Saudi Arabia. J Family Community Med. 2011 Jan;18(1):8-12. doi:10.4103/1319-1683.78631

8. Reisi M, Javadzade SH, Shahnazi H, Sharifirad G, Charkazi A, Moodi M. Factors affecting cigarette smoking based on health-belief model structures in pre-university students in Isfahan, Iran. J Educ Health Promot. 2014;3:23. doi:10.4103/2277-9531.127614

9. Turhan E, Inandi T, Col M, Bugdayci R, Eker O, Ilhan M. Smoking cessation and attitudes, belief, observation, and education of medical students, in Turkey. J Nepal Med Assoc. 2016;54:55-62. PMID:27935924

10. Larson NI, Story M, Perry CL, Neumark-Sztainer D, Hannan PJ. Are diet and physical activity patterns related to cigarette smoking in adolescents? Findings from Project EAT. Prev Chronic Dis. 2007;4:A51. PMID:17572955

11. Reichenberger DA, Hilmert CJ, Irish LA, Secor-Turner M, Randall BA. Associations between sleep and health-risk behaviors in a rural adolescent population. J Pediatr Health Care. 2016;30:317-22. doi:10.1016/j.pedhc.2015.08.003

12. Jarosz M, Sekula W, Rychlik E. Trends in dietary patterns, alcohol intake, tobacco smoking, and colorectal cancer in Polish population in 1960-2008. Biomed Res Int. 2013;2013:183204. doi:10.1155/2013/183204

13. Brinker TJ, Owczarek AD, Seeger W, Groneberg DA, Brieske CM, Jansen P, et al. A Medical student-delivered smoking prevention program, education against tobacco, for secondary schools in Germany: randomized controlled trial. J Med Internet Res. 2017;19:e199. doi:10.2196/jmir.7906

14. Krist L, Lotz F, Burger C, Strobele-Benschop N, Roll S, Rieckmann N, et al. Long-term effectiveness of a combined student-parent and a student-only smoking prevention intervention among 7th grade school children in Berlin, Germany. Addiction. 2016;111:2219-29. doi:10.1111/add.13537

15. Shadur JM, Ninnemann AL, Lim A, Lejuez CW, MacPherson L. The prospective relationship between distress tolerance and cigarette smoking expectancies in adolescence. Psychol Addict Behav. 2017;31:625-35. doi:10.1037/adbooo0300

16. Siegel A, Korbman M, Erblich J. Direct and indirect effects of psychological distress on stress-induced smoking. J Stud Alcohol Drugs. 2017;78:930-7. DOI:10.15288/jsad.2017.78.930

17. Mansouri M, Sharifi F, Varmaghani M, Yaghubi H, Tabrizi YM, Raznahan M, et al. Iranian university students lifestyle and health status survey: study profile. J Diabetes Metab Disord. 2017;16:48. doi:10.1186/s40200-017-0329-z

18. Sarraf-Zadegan N, Boshtam M, Shahrokhi S, Naderi GA, Asgary S, Shahparian M, et al. Tobacco use among Iranian men, women and adolescents. Eur J Public Health. 2004;14:76-8. doi:10.1093/eurpub/14.1.76

19. Finch K, Novotny TE, Ma S, Qin D, Xia W, Xin G. Smoking knowledge, attitudes, and behaviors among rural-to-urban migrant women in Beijing, China. Asia Pac J Public Health. 2010;22:342-53. doi:10.1177/1010539509335034

20. Dabbagh-Moghadam A, Mozaffari-Khosravi H, Nasiri M, Miri A, Rahdar M, Sadeghi O. Association of white and red meat consumption with general and abdominal obesity: a cross-sectional study among a population of Iranian military families in 2016. Eat Weight Disord. 2017;22:717-24. doi:10.1007/s40519-017-0385-X

21. Sadeghi O, Maghsoudi Z, Nasiri M, Khorvash F, Askari G. The association between anthropometric measurements and severity, frequency and duration of headache attacks in adults with migraine in Isfahan. J Mazandaran Univ Med Sci. 2014;24:194-203.

22. Mansouri M, Miri A, Varmaghani M, Abbasi R, Taha P, Ramezani S, et al. Vitamin D deficiency in relation to general and abdominal obesity among high educated adults. Eat Weight Disord. 2018. doi:10.1007/s40519-018-0511-4

23. Lim JU, Lee JH, Kim JS, Hwang YI, Kim TH, Lim SY, et al. Comparison of World Health Organization and Asia-Pacific body mass index classifications in COPD patients. Int J Chron Obstruct Pulmon Dis. 2017;12:2465-75. doi:10.2147/COPD.S141295

24. Primack BA, Shensa A, Kim KH, Carroll MV, Hoban MT, Leino EV, et al. Waterpipe smoking among U.S. university students. Nicotine Tob Res. 2013;15:29-35. doi:10.1093/ntr/nts076

25. Agaku IT, Filippidis FT, Vardavas CI, Odukoya OO, Awopegba AJ, Ayo-Yusuf OA, et al. Poly-tobacco use among adults in 44 countries during 2008-2012: evidence for an integrative and comprehensive approach in tobacco control. Drug Alcohol Depend. 2014;139:60-70. doi:10.1016/j.drugalcdep.2014.03.003

26. Pennanen M, Broms U, Korhonen T, Haukkala A, Partonen T, Tuulio-Henriksson A, et al. Smoking, nicotine dependence and nicotine intake by socio-economic status and marital status. Addict Behav. 2014;39:1145-51. PMID:24727110

27. Sarrafzadegan N, Toghianifar N, Roohafza H, Siadat Z, Mohammadifard N, O'Loughlin J. Lifestyle-related determinants of hookah and cigarette smoking in Iranian adults. J Community Health. 2010;35:36-42. doi:10.1007/s10900-009-9186-0

28. Derrick JL, Leonard KE, Homish GG. Perceived partner responsiveness predicts decreases in smoking during the first nine years of marriage. Nicotine Tob Res. 2013;15:1528-36. doi:10.1093/ntr/ntto11 
29. Thompson AB. Smoking initiation after marriage and parenting among black and white women. Am J Health Behav. 2014;38:577-85. doi:10.5993/AJHB.38.4.11

30. Azagba S, Sharaf MF. The effect of job stress on smoking and alcohol consumption. Health Econ Rev. 2011;1:15. doi:10.1186/21911991-1-15

31. Kaiser M, Reutter M, Sousa-Poza A, Strohmaier K. Smoking and local unemployment: evidence from Germany. Econ Hum Biol. 2018;29:138-47. doi:10.1016/j.ehb.2018.02.004

32. Heikkila K, Nyberg ST, Fransson EI, Alfredsson L, De Bacquer D, Bjorner JB, et al. Job strain and tobacco smoking: an individual-participant data meta-analysis of 166,130 adults in 15 European studies. PLoS One. 2012;7:e35463. doi:10.1371/journal. pone.0035463

33. Lee YY, Khoo S, Morris T, Hanlon C, Wee LH, Teo EW, et al. A mixed-method study of the efficacy of physical activity consultation as an adjunct to standard smoking cessation treatment among male smokers in Malaysia. Springerplus. 2016;5:2012. doi:10.1186/s40064-016-3675-2

34. Werneck AO, Oyeyemi AL, Silva DR. Physical activity and depression: is 150 min/week of moderate to vigorous physical activity a necessary threshold for decreasing risk of depression in adults? Different views from the same data. Soc Psychiatry Psychiatr Epidemiol. 2018. doi:10.1007/s00127-018-1490-5

35. Pengpid S, Peltzer K. Vigorous physical activity, perceived stress, sleep and mental health among university students from 23 low- and middle-income countries. Int J Adolesc Med Health. 2018. doi:10.1515/ijamh-2017-0116

36. Wood CJ, Clow A, Hucklebridge F, Law R, Smyth N. Physical fitness and prior physical activity are both associated with less cortisol secretion during psychosocial stress. Anxiety Stress Coping. 2018;31:135-45. doi:10.1080/10615806.2017.1390083

37. Primack BA, Fertman CI, Rice KR, Adachi-Mejia AM, Fine MJ. Waterpipe and cigarette smoking among college athletes in the United States. J Adolesc Health. 2010;46:45-51. doi:10.1016/j.jadohealth.2009.05.004

38. Chen LJ, Steptoe A, Chen YH, Ku PW, Lin CH. Physical activity, smoking, and the incidence of clinically diagnosed insomnia. Sleep Med. 2017;30:189-94. doi:10.1016/j.sleep.2016.06.040

39. Kalmbach DA, Pillai V, Drake CL. Nocturnal insomnia symptoms and stress-induced cognitive intrusions in risk for depression: a 2-year prospective study. PLoS One. 2018;13:e0192088. doi:10.1371/journal.pone.0192088

40. Zheng WH, Wakim RJ, Geary RC, Lander LR, Wen SJ, Xiao MC, et al. Self-reported sleep improvement in buprenorphine MAT (Medication Assisted Treatment) population. Austin J Drug Abuse Addict. 2016;3. PMID:28133635

41. Lee BH, Lee HK. Longitudinal study shows that addictive Internet use during adolescence was associated with heavy drinking and smoking cigarettes in early adulthood. Acta Paediatr. 2017;106:497-502. doi:10.1111/apa.13706

42. Mei S, Gao T, Li J, Zhang Y, Chai J, Wang L, et al. Internet addiction in college students and its relationship with cigarette smoking and alcohol use in Northeast China. Asia Pac Psychiatry. 2017;9(4). doi:10.1111/appy.12281

43. Arcury TA, Sandberg JC, Melius KP, Quandt SA, Leng X, Latulipe C, et al. Older adult internet use and ehealth literacy. J Appl Gerontol. 2018 Oct 24:733464818807468. doi:10.1177/0733464818807468

44. Fawns-Ritchie C, Starr JM, Deary IJ. Health literacy, cognitive ability and smoking: a cross-sectional analysis of the English Longitudinal Study of Ageing. BMJ Open. 2018;8:e023929. doi:10.1136/bmjopen-2018-023929

45. Kim DH. Association between subjective obesity status and smoking behavior among normal-weight women. Health Educ Behav. 2017:1090198117728992. doi:10.1177/1090198117728992

46. Aldahash FD, Alasmari SA, Alnomsi SJ, Alshehri AM, Alharthi NF, Aloufi AAH, et al. Relationship of body mass index to sleep duration, and current smoking among medical students in Tabuk City, Saudi Arabia. Electron Physician. 2018;10:7273-8. doi:10.19082/7273

47. Jeffery RW, McGuire MT, French SA. Prevalence and correlates of large weight gains and losses. Int J Obes Relat Metab Disord. 2002;26:969-72. doi:10.1038/sj.ijo.0802015

48. Rezaei S, Hajizadeh M, Pasdar Y, Hamzeh B, Moradinazar M, Najafi F. Association of smoking with general and abdominal obesity: evidence from a cohort study in west of Iran. J Res Health Sci. 2017;18:e00401. PMID:29445047

49. Asgari F, Biglarian A, Seifi B, Bakhshi A, Miri HH, Bakhshi E. Using quadratic inference functions to determine the factors associated with obesity: findings from the STEPS Survey in Iran. Ann Epidemiol. 2013;23:534-8. doi:10.1016/j.annepidem.2013.07.006

50. Sutaria S, Devakumar D, Yasuda SS, Das S, Saxena S. Is obesity associated with depression in children? Systematic review and meta-analysis. Arch Dis Child. 2019 Jan;104(1):64-74. doi:10.1136/archdischild-2017-314608

51. Baker KD, Loughman A, Spencer SJ, Reichelt AC. The impact of obesity and hypercaloric diet consumption on anxiety and emotional behavior across the lifespan. Neurosci Biobehav Rev. 2017;83:173-82. doi:10.1016/j.neubiorev.2017.10.014

52. Sadeghi O, Hassanzadeh-Keshteli A, Afshar H, Esmaillzadeh A, Adibi P. The association of whole and refined grains consumption with psychological disorders among Iranian adults. Eur J Nutr. 2019 Feb;58(1):211-25. doi:10.1007/s00394-017-1585-X

53. Nicklas BJ, Tomoyasu N, Muir J, Goldberg AP. Effects of cigarette smoking and its cessation on body weight and plasma leptin levels. Metabolism. 1999;48:804-8. doi:10.1016/s0026-0495(99)90183-X

54. Zhang WX, Li YP, Fan J, Chen HJ, Li GL, Ouyang YQ, et al. Perinatal nicotine exposure increases obesity susceptibility by peripheral leptin resistance in adult female rat offspring. Toxicol Lett. 2018;283:91-9. doi:10.1016/j.toxlet.2017.11.015 
55. Wang M, Wang H, Fei FR, Xu CX, Du XF, Zhong JM. The associations between cigarette smoking and health-related behaviors among Chinese school-aged adolescents. Tob Induc Dis. 2017;15:27. doi:10.1186/s12971-017-0132-0

56. Weinrauch LA, D’Elia JA. Is skipping breakfast a marker for current smoking? J Am Coll Cardiol. 2018;71:707-8. doi:10.1016/j. jacc.2017.10.103

57. Suh SY, Lee JH, Park SS, Seo AR, Ahn HY, Bae WK, et al. Less healthy dietary pattern is associated with smoking in Korean men according to nationally representative data. J Korean Med Sci. 2013;28:869-75. doi:10.3346/jkms.2013.28.6.869

58. Heydari G, Heidari F, Yousefifard M, Hosseini M. Smoking and diet in healthy adults: a cross-sectional study in Tehran, Iran, 2010. Iran J Public Health. 2014;43:485-91. PMID:26005659

59. Haibach JP, Homish GG, Collins RL, Ambrosone CB, Giovino GA. An evaluation of fruit and vegetable consumption and cigarette smoking among youth. Nicotine Tob Res. 2015;17:719-26. doi:10.1093/ntr/ntu215

6o. Lee YH, Wang Z, Chiang TC, Liu CT. Beverage intake, smoking behavior, and alcohol consumption in contemporary China-a cross-sectional analysis from the 2011 China Health and Nutrition Survey. Int J Environ Res Public Health. $2017 ; 14$. PMID:28481283

61. Lee B, Yi Y. Smoking, Physical activity, and eating habits among adolescents. West J Nurs Res. 2016;38:27-42. doi:10.1177/0193945914544335

62. Kim EK, Kim H, Vijayakumar A, Kwon O, Chang N. Associations between fruit and vegetable, and antioxidant nutrient intake and age-related macular degeneration by smoking status in elderly Korean men. Nutr J. 2017;16:77. doi:10.1186/s12937-017-0301-2

63. Mariapun J, Hairi NN, Ng CW. Socioeconomic differences in smoking and cessation across a period of rapid economic growth in an upper-middle-income country. Nicotine Tob Res. 2019 Oct 26;21(11):1539-46. doi:10.1093/ntr/nty203

64. Kusumawardani N, Tarigan I, Suparmi, Schlotheuber A. Socio-economic, demographic and geographic correlates of cigarette smoking among Indonesian adolescents: results from the 2013 Indonesian Basic Health Research (RISKESDAS) survey. Glob Health Action. 2018;11:1467605. doi:10.1080/16549716.2018.1467605

65. Dijkstra SC, Neter JE, Brouwer IA, Huisman M, Visser M, van Lenthe FJ, Kamphuis CB. Socio-economic differences in the change of fruit and vegetable intakes among Dutch adults between 2004 and 2011: the GLOBE study. Public Health Nutr. 2018;21:1704-16. doi:10.1017/S1368980017004219

66. Papadopoulos D, Kikemeni A, Skourti A, Amfilochiou A. The influence of socio-economic status on the severity of obstructive sleep apnea: a cross-sectional observational study. Sleep Sci. 2018;11:92-8. doi:10.5935/1984-0063.20180018

67. George AM, da Silva JA, Bandeira AD, Filho VC, Rohr LE, Lopes AD, et al. Association between socio-economic status and physical activity is mediated by social support in Brazilian students. J Sports Sci. 2018;20:1-7. doi:10.1080/02640414.2018.1509435 